\title{
Antigastric Antibodies in Hyperthyroidism: Their Relationship to Impaired Acid Secretion
}

\author{
M. J. WILLIAMS, * M.D., M.R.C.P.; G. B. SCOTT, $\dagger$ M.B., M.C.PATH. \\ J. S. BECK, $\dagger$ M.D., B.SC., M.R.C.P.ED., M.R.C.P.GLAS., M.C.PATH. ; D. W. BLAIR, $\ddagger$ M.D., CH.M., F.R.C.S.ED.
}

Brit. med. F., 1966, 1, 388-391

It was recently shown by means of the augmented histamine test that there was an increased incidence of achlorhydria in patients with hyperthyroidism, and that the mean acid output was considerably less than in normal subjects (Williams and Blair, 1964). No correlation was found between the level of acid secretion and the severity or duration of the hyperthyroidism, and the acid output did not increase after successful control of thyroid function. Gastric biopsies, however, suggested that the reduction in acid secretion was related to the presence of some degree of gastritis. Round-cell infiltration and lymph-follicle formation were also often noted in the gastric mucosa, and because of these appearances, and the recent demonstration of an increased incidence of antigastric antibody in patients with hyperthyroidism (Doniach et al., 1963 ; Irvine, 1963a), it was suggested that the changes in gastric secretion in these patients may have an immunological basis. Tests for antigastric antibody have now been performed on a group of patients with hyperthyroidism by means of the immunofluorescent technique, which demonstrates the reaction of this antibody with a particulate component of parietal-cell cytoplasm and is the most sensitive method at present available for its detection (Irvine, 1963b). The results have been correlated with the changes in gastric secretion and other clinical findings.

\section{Materials and Methods}

Forty patients with hyperthyroidism were studied, including 28 of the patients previously reported (Williams and Blair, 1964. There were 32 females and 8 males, their ages ranging from 20 to 65 (mean 44 years). The augmented histamine tests, gastric biopsies, and investigations of thyroid function were performed as reported previously. The augmented histamine tests and gastric biopsies were performed only on patients who agreed voluntarily to these studies after the purpose of the investigation had been explained to them. The gastric biopsies were graded histologically according to the classification devised by Bock et al. (1963). All the patients were treated for the disease, and the interval between the investigation of gastric function and the removal of serum for antigastric antibody tests ranged from 4 to 24 months (mean interval 15 months). Serum was also obtained from 40 hospital control patients matched for sex and age with the hyperthyroid patients. These control patients were either healthy members of the hospital staff or patients in the medical or surgical wards of the hospital; none had evidence of gastro-intestinal or thyroid disease, and all had haemoglobin levels greater than $11.6 \mathrm{~g} . / 100 \mathrm{ml}$.

Antigastric antibodies were detected by an indirect fluorescent antibody technique. Cryostat sections of human $\mathrm{O}$ stomach were treated in a moist chamber with undiluted sera for 30 minutes at room temperature. The unattached serum proteins were removed by washing for 10 minutes, with

\footnotetext{
* Department of Materia Medica and Therapeutics, University of

A Aberdeen.

$\ddagger$ Department of Surgery, University of Aberdeen.
}

agitation, in $0.15 \mathrm{M} \mathrm{NaCl}$ buffered at $p \mathrm{H} 7.2$ with $10 \% 0.15 \mathrm{M}$ phosphate buffer. The sections were then treated with fluorescein-conjugated rabbit antihuman $\gamma$-globulin for 30 minutes and after washing for 10 minutes were mounted in phosphate-buffered glycerol $(p \mathrm{H} 7.2)$. The sections were then examined with dark-ground blue-violet/ultra-violet illumination on a horizontal optical system similar to that designed by Young (1961).

The specificity of the fluorescein-conjugated antihuman $\gamma$-globulin staining was confirmed by specific absorption with human $\gamma$-globulin prepared by DEAE Sephadex chromatography of normal human serum, and by failure of absorption with other human serum proteins. All sera were tested without prior knowledge of the diagnosis made on the patients, and the intensity of parietal-cell staining, when present, was assessed visually on a three-point scale as,+++++ , or + .

\section{Results}

Incidence of Antigastric Antibody.-The findings are shown in Table I. Antigastric antibody was found in $15(37.5 \%)$ of the hyperthyroid patients and in only $4(1.0 \%)$ of the matched controls, this difference being highly significant $(\mathrm{P}<0.01)$. Of the 15 hyperthyroid patients with antigastric antibody five were +++ , six ++ , and four + . Of the positive controls two were +++ , and one each ++ and + . As the number of male patients and male controls was small, no conclusions can be drawn about the relative sex incidence of antigastric antibody.

Table I.-Antigastric Antibodies in Patients with Hyperthyroidism and in Matched Controls

\begin{tabular}{|c|c|c|c|c|c|}
\hline & \multirow{2}{*}{ Sex } & \multirow{2}{*}{$\begin{array}{l}\text { Total } \\
\text { No. }\end{array}$} & \multirow{2}{*}{$\underset{\text { (Years) }}{\text { Mean Age }}$} & \multicolumn{2}{|c|}{ Antigastric Antibodies } \\
\hline & & & & No. & Incidence \\
\hline \multirow{2}{*}{$\begin{array}{l}\text { Hyperthyroid } \\
\text { patients }\end{array}$} & $\underset{\mathrm{M}}{\mathrm{F}}$ & $\begin{array}{r}32 \\
8\end{array}$ & $\begin{array}{l}43 \cdot 4 \\
47 \cdot 0\end{array}$ & $\begin{array}{r}11 \\
4\end{array}$ & $\begin{array}{l}34 \cdot 3 \% \\
50 \%\end{array}$ \\
\hline & Total & 40 & $44 \cdot 1$ & 15 & $37.5 \%$ \\
\hline \multirow{2}{*}{ Matched controls } & $\underset{\mathrm{M}}{\mathrm{F}}$ & $\begin{array}{r}32 \\
8\end{array}$ & $\begin{array}{l}43 \cdot 4 \\
47 \cdot 4\end{array}$ & $\begin{array}{l}4 \\
0\end{array}$ & $\begin{array}{l}12.5 \% \\
0 \%\end{array}$ \\
\hline & Total & 40 & $44 \cdot 2$ & 4 & $10 \%$ \\
\hline
\end{tabular}

Relationship of Antigastric Antibody to Level of Acid Secretion.-The frequency distribution of the maximal acid output in the hyperthyroid patients with and without antigastric antibodies is shown in Fig. 1. Histamine-fast achlorhydria was present in $8(20 \%)$ of the hyperthyroid patients, and the sera of six of these patients contained antigastric antibody. In the whole series the presence of antigastric antibody was always associated with low acid secretion (range 0.00-6.00 $\mathrm{mEq} \mathrm{HCl}$; mean $2.22 \mathrm{mEq}$ ), while in those without antibody a wide range of acid outputs was found (range $0.00-29.96 \mathrm{mEq}$ $\mathrm{HCl}$; mean $9.92 \mathrm{mEq}$ ). The difference between the mean acid outputs in these two groups is highly significant $(\mathbf{P}<0.001)$. Within the group with positive antibody tests there was no evidence of any relationship between the intensity of staining 
in the fluorescent antibody test and the level of acid secretion, though the numbers are too small for precise analysis.

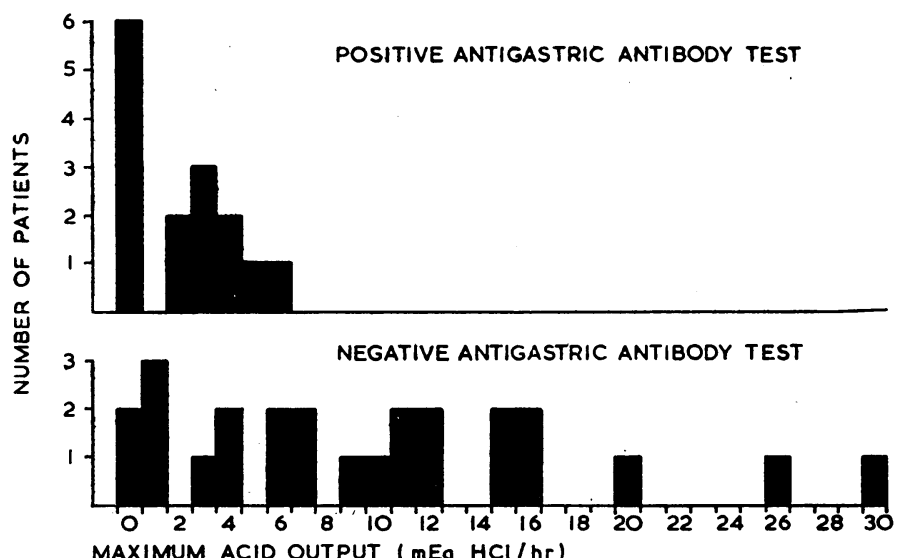

FIG. 1.-Frequency distributions of maximum acid output in hyperthyroid patients with positive and negative antigastric antibody tests. Acid output in patients with histamine-fast achlorhydria recorded as $0 \mathrm{mEq} \mathrm{HCl}$.

Relationship of Antigastric Antibody to Gastric Mucosal Appearances.-Gastric biopsies had previously been obtained in nine of the hyperthyroid patients, and the histological findings are shown in Table II with the results of the antigastric antibody tests. In the three patients with antigastric antibody in their serum the gastric mucosa showed variable degrees of gastritis, the appearances in two patients being those of atrophic gastritis with less-marked changes of superficial gastritis in the third patient. Similar degrees of gastritis were, however, found in another five patients without antigastric antibody having been demonstrated. In the one patient with a completely normal gastric mucosa the antigastric antibody test was negative. Round-cell infiltration and lymph-follicle formation were often noted but did not relate to the presence or absence of demonstrable antibody.

TABLE II.-Gastric Biopsy Findings and Results of Antigastric Antibody Tests in Hyperthyroid Patients

\begin{tabular}{|c|c|c|c|c|c|c|}
\hline \multirow{3}{*}{ Patient } & \multirow{3}{*}{$\begin{array}{l}\text { Anti- } \\
\text { gastric } \\
\text { Anti- } \\
\text { bodies }\end{array}$} & \multirow{3}{*}{$\begin{array}{c}\text { Site } \\
\text { of } \\
\text { Biopsy }\end{array}$} & \multicolumn{3}{|c|}{ Histological Findings } & \multirow{3}{*}{$\begin{array}{l}\text { Lymph- } \\
\text { Follicle } \\
\text { Forma- } \\
\text { tion }\end{array}$} \\
\hline & & & \multirow{2}{*}{ Gross Appearances } & \multicolumn{2}{|c|}{$\begin{array}{c}\text { Diffuse Cellular } \\
\text { Infiltration }\end{array}$} & \\
\hline & & & & $\begin{array}{l}\text { Lympho- } \\
\text { cytes }\end{array}$ & $\begin{array}{c}\text { Plasma } \\
\text { Cells }\end{array}$ & \\
\hline \multirow{5}{*}{$\begin{array}{l}\text { E.R. } \\
\text { J.L. } \\
\text { J.T. } \\
\text { J.M. } \\
\text { S.S. } \\
\text { W.B. } \\
\text { H.D. } \\
\text { G.McL. } \\
\text { H.C. }\end{array}$} & \multirow{5}{*}{$\begin{array}{c}\overline{-} \\
+\bar{t}+ \\
++ \\
\overline{+} \\
++\end{array}$} & $\begin{array}{l}\text { Fundus } \\
\text { \# }\end{array}$ & $\begin{array}{l}\text { Atrophic gastritis } \\
\text { Superficial gastritis }\end{array}$ & \pm & $\begin{array}{l}+ \\
\pm\end{array}$ & $\begin{array}{l}+ \\
+\end{array}$ \\
\hline & & $\begin{array}{l}\text { Pylorus } \\
\text { Fundus }\end{array}$ & " ", & \pm & $\stackrel{+}{+}+$ & $\bar{t}$ \\
\hline & & " & Atrophic gastritis & $\stackrel{+}{+}$ & + & + \\
\hline & & ", & $\begin{array}{l}\text { Normal } \\
\text { Atrophic gastritis }\end{array}$ & $\bar{t}$ & $\overline{+}$ & $\overline{+}$ \\
\hline & & & " & + & ++ & + \\
\hline
\end{tabular}

Relationship of Antigastric Antibody to the Previous Thyroid Disease.-No correlation was found between the presence or absence of antigastric antibody and the severity or duration of the previous hyperthyroidism. The severity of the disease was assessed by the score on the clinical diagnostic index (Crooks et al., 1959), and the incidence of antigastric antibody in those who had previously had moderate toxicity (index +20 to +30 ) was similar to that found in the patients who had been severely toxic (index over +31$)(P>0.1)$. The duration of the previous hyperthyroidism was obtained from the history, and the incidence of positive antigastric antibody tests was similar in those with symptoms of less than one year and in those who had had symptoms for a longer period $(P>0.1)$. All the patients had received specific treatment for their thyroid disease-13 with antithyroid drugs followed by partial thyroidectomy, and 26 with therapeutic doses of radioiodine. One patient had received both forms of treatment, radioiodine being given after a post-operative recurrence. The incidence of antigastric antibody in the two groups of patients is shown in Table III. The difference found is not significant $(P>0.5)$.

Table III.-Antigastric Antibodies in Patients with Treated Hyperthyroidism in Relation to Method of Treatment

\begin{tabular}{|c|c|c|c|c|c|}
\hline \multirow{2}{*}{\multicolumn{3}{|c|}{ Method of Treatment }} & \multirow{3}{*}{$\begin{array}{c}\begin{array}{c}\text { No. of } \\
\text { Patients }\end{array} \\
13 \\
26\end{array}$} & \multicolumn{2}{|c|}{ Antigastric Antibodies } \\
\hline & & & & No. & Incidence \\
\hline $\begin{array}{l}\text { Antithyroid drugs }+ \text { operation } \\
\text { Radioiodine } \ldots \\
\text {.. }\end{array}$ & $\therefore$ & $\therefore$ & & $\begin{array}{l}6 \\
9\end{array}$ & $\begin{array}{l}46 \cdot 1 \% \\
34 \cdot 6 \%\end{array}$ \\
\hline
\end{tabular}

Relationship of Antigastric Antibodies to Antithyroid Antibodies.-Significant titres of antithyroglobulin antibodies (positive precipitin test or tanned-red-cell test $>1 / 25,000$ ) suggestive of coincident thyroid autoimmunity had been found in five of the female hyperthyroid patients, but none showed a positive complement-fixation test with thyroid extract. Only two of these with antithyroglobulin had antigastric antibody, and in both cases the test was assessed as +++ . Thus the incidence of antigastric antibody in these patients was similar to that of those without significant antithyroid antibody titres $(13 / 35)$.

Influence of Age.-The frequency distribution of the ages of the hyperthyroid patients with and without antigastric antibody is shown in Fig. 2: The mean ages of the two groups were 42.5 years and 45.2 years respectively, and although the incidence of antigastric antibody appears to be highest in the middle-age groups this probably merely reflects the preponderance of middle-aged patients in the series.

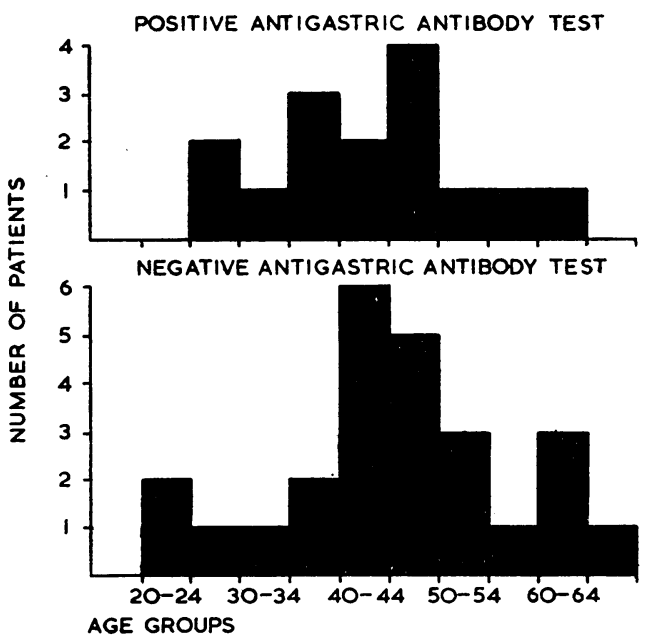

FIG. 2.-Frequency distributions of ages of hyperthyroid patients with positive and negative antigastric antibody tests.

Influence of Anaemia.-Significant anaemia ( $\mathrm{Hb}<11.6$ g./ $100 \mathrm{ml}$.) was present in nine female patients, but the incidence of antigastric antibody (3/9) was no higher in these patients than in those without anaemia $(12 / 31)(P>0.1)$. The anaemia always appeared to be due to iron deficiency, being associated with a low M.C.H.C. and responding fully to oral iron therapy.

Table IV.-Haematological and Other Data in Hyperthyroid Patients with Achlorhydria

\begin{tabular}{|c|c|c|c|c|c|c|c|}
\hline Patient & $\begin{array}{c}\text { Age } \\
\text { (Years) }\end{array}$ & Sex & $\begin{array}{l}\text { Anti- } \\
\text { gastric } \\
\text { Anti- } \\
\text { bodies }\end{array}$ & $\underset{\substack{\text { (g. } / 100 \\
\text { ml. })}}{\mathrm{Hb}}$ & $\begin{array}{c}\text { M.C.H.C. } \\
\text { (normal } \\
32-36 \%)\end{array}$ & $\begin{array}{c}\text { Serum } \mathbf{B}_{12} \\
\mu \mu \mathrm{g} . / \mathrm{ml} . \\
\text { (normal } \\
\text { range } \\
160-900 \\
\mu \mu \mathrm{g} . / \mathrm{ml} .)\end{array}$ & $\begin{array}{c}{ }^{58} \mathrm{CoB}_{12} \\
\text { Absorp- } \\
\text { tion }\end{array}$ \\
\hline $\begin{array}{l}\text { J.McC. } \\
\text { M.W. } \\
\text { J.T. } \\
\text { E.R. } \\
\text { M.H. } \\
\text { B.L. } \\
\text { S.S. } \\
\text { A.D. }\end{array}$ & $\begin{array}{l}47 \\
47 \\
61 \\
54 \\
65 \\
38 \\
58 \\
32\end{array}$ & $\begin{array}{l}\mathrm{F} \\
\mathrm{F} \\
\mathrm{F} \\
\mathrm{F} \\
\mathrm{F} \\
\mathrm{F} \\
\mathbf{M} \\
\mathbf{M}\end{array}$ & $\begin{array}{c}+ \\
+++ \\
++ \\
\pm \\
++ \\
++ \\
+\end{array}$ & $\begin{array}{l}11.5 \\
11.5 \\
11.0 \\
13.6 \\
11.7 \\
11.7 \\
14.0 \\
14.6\end{array}$ & $\begin{array}{l}28.5 \% \\
30.0 \% \\
31.5 \% \\
32.0 \% \\
33.0 \% \\
31.0 \% \\
32.3 \% \\
32.0 \%\end{array}$ & $\begin{array}{l}428 \\
224 \\
172 \\
596 \\
452 \\
400 \\
296 \\
232\end{array}$ & $\begin{array}{c}\text { Normal } \\
" ” \\
" \\
\text { " }\end{array}$ \\
\hline
\end{tabular}


More detailed studies were performed on the eight patients with achlorhydria, and the results are shown in Table IV. Iron-deficiency anaemia was present in three patients, but was marked in only one (J. T.). Serum vitamin- $B_{12}$ levels, measured microbiologically with Lactobacillus leichmannii as test organism, were within the normal range $(160-900 \mu \mu \mathrm{g} . / \mathrm{ml}$.) in all patients, though one patient (J. T.) had a rather borderline level of $172 \mu \mu \mathrm{g} . / \mathrm{ml}$. Vitamin-B $\mathrm{B}_{12}$ absorption, determined by the hepatic-uptake method using ${ }^{58} \mathrm{CoB}_{12}$ (Glass et al., 1954), was, however, normal in this patient, as it was in the four others in whom it was measured.

\section{Discussion}

The present findings confirm the occurrence of antigastric antibody in a significant proportion of patients with hyperthyroidism, the incidence of $37.5 \%$ being significantly greater than the $10 \%$ incidence found in matched controls. These results confirm the findings of Doniach et al. (1963), who used a similar technique.

Though the tests for antigastric antibody and the studies of gastric function in the hyperthyroid patients were not performed contemporaneously, we consider that the results can justifiably be compared, as serum titres of this antibody are known to be extremely stable (Irvine, 1963b), while the augmented histamine test has also been shown to give remarkably consistent results when repeated in the same individual over periods up to two years (Sircus, 1959 ; Marks and Shay, 1961). The presence of antigastric antibody in the hyperthyroid patients correlated well with the previously demonstrated reduction in acid secretion. Thus antigastric antibody was found in six of the eight patients who had achlorhydria, and the other patients with antigastric antibody invariably had a low acid output in response to histamine. In the patients with negative antibody tests, on the other hand, a much wider range of acid outputs was found, and though some of these patients also had low acid secretions the mean acid output for this group was significantly higher than that in the group with positive antibody tests.

A similar correlation between the occurrence of antigastric antibody and achlorhydria has been noted previously in patients with spontaneous hypothyroidism (Irvine et al., 1962), in idiopathic adrenal insufficiency (Irvine, 1963c), and in irondeficiency anaemia (Dagg et al., 1964). In a later study of 46 patients with spontaneous hypothyroidism or autoimmune thyroiditis Irvine et al. (1963) also noted a fair correlation between the titre of complement-fixing antigastric antibody and the level of acid secretion following histamine stimulation.

It has recently been suggested that the common factor in patients with antigastric antibody is the presence of some degree of gastritis (Adams et al., 1964 ; te Velde et al., 1964), and this was noted in the three patients in the present series who had antigastric antibody in the serum and had previously had gastric biopsies. Equally severe changes of gastritis were, however, found in other patients without antigastric antibody being present, as has been noted also in patients with iron-deficiency anaemia (Adams et al., 1964 ; Dagg et al., 1964). Such findings are quite compatible with the concept that the gastritis may have an autoimmune basis, as it is not necessary that the sera of all patients with the disease should contain antibody (Irvine, 1963b). There is no evidence that antigastric antibody itself, in common with the other organ-specific antibodies, has any pathogenic significance, its presence simply being an indication of immunological activity involving the stomach. Antibody may be produced locally by plasma cells without there being sufficient leakage into the circulation to allow of its detection in the serum, or, alternatively, the changes in the gastric mucosa may be produced by cell-bound antibody, probably carried by lymphocytes, in the absence of any demonstrable free antibody in the serum (Irvine, 1963b). In the light of these suggestions it is of interest that cellular infiltration with both plasma cells and lymphocytes was commonly noted in the gastric biopsy specimens.

The presence of antigastric antibody in the hyperthyroid patients was not related to the severity or duration of the previous thyroid disease, to the method of treatment employed, or to the ages of the patients. It also appeared to be unrelated to the occurrence of antithyroid antibody, but Anderson et al. (1964) have shown in a large series of hyperthyroid patients that there is a significantly higher incidence of antigastric antibody in patients with antithyroid antibody than in those without such antibody. These antibody systems are, however, quite distinct, antigastric antibody being both organ- and cellspecific (Taylor et al., 1962 ; Irvine, 1963b).

This immunological reaction involving the stomach is not related merely to the presence of thyroid disease, as the incidence of antigastric antibody is not increased in patients with simple goitre (Irvine, 1963a), whereas an increased incidence is found in both Hashimoto's disease and hyperthyroidism (Doniach et al., 1963). Autoimmune phenomena are strongly implicated in Hashimoto's disease (Doniach and Roitt, 1961), and it has been suggested that hyperthyroidism itself may also have an autoimmune basis (Anderson et al., 1964), a viewpoint supported by the finding of a high incidence of medullary lymphoid follicle formation in thymic biopsies from such patients (Gunn et al., 1964).

If a basic disturbance of immunological tolerance in hyperthyroidism is confirmed, then the gastritis and changes in acid secretion could also result from an autoimmune mechanism, with the associated formation of antigastric antibodies. The relationship shown in the present patients between the presence of antigastric antibody and the level of acid secretion would be in keeping with such a hypothesis.

If progressive these changes in the gastric mucosa could lead to loss of intrinsic-factor secretion, with the development of latent or overt pernicious anaemia, and the association of this condition with hyperthyroidism is now well recognized (McNicol, 1961 ; Doniach et al., 1963). Bock and Witts (1963) studied 46 patients who had been treated for thyrotoxicosis between one and nine years previously and found that four had complete or practically complete achlorhydria, and two of these patients had latent pernicious anaemia. No example of this condition was found in the eight hyperthyroid patients who had achlorhydria in the present series, but since patients with antigastric antibody are probably more prone to develop pernicious anaemia (Adams et al., 1964) this condition may yet appear in some of these patients.

\section{Summary}

An immunofluorescent technique has been used to detect antigastric antibodies in a group of 40 hyperthyroid patients, and the results are correlated with changes in gastric secretion and other clinical findings.

Antigastric antibodies were found in $37.5 \%$ of the hyperthyroid patients, compared with an incidence of $10 \%$ in a simultaneously studied group of matched controls, this difference being statistically significant.

The presence of antigastric antibody was related to the finding of impaired acid secretion and to the finding of changes of gastritis in gastric biopsy specimens, but unrelated to the severity or duration of the previous hyperthyroidism or to its method of treatment. No correlation was found either between the occurrence of antigastric antibodies and antithyroid antibodies or with the presence of anaemia.

The significance of these findings is discussed, and it is suggested that some patients with hyperthyroidism have a coincident autoimmune lesion involving the stomach, leading to gastritis and depression of acid secretion. The relationship 
of these findings to the possible autoimmune nature of hyperthyroidism itself is discussed.

We are grateful to Dr. Audrey Dawson for the serum vitamin$B_{12}$ estimations and to Dr. S. D. Mohamed for the vitamin-B absorption studies. We also thank Miss Sheila Tait for technical help with the serological studies.

\section{REFERENCES}

Adams, J. F., Glen, A. I. M., Kennedy, E. H., Mackenzie, I. L., Morrow, J. M., Anderson, J. R., Gray, K. G., and Middleton, D. G. (1964). Lancet, 1, 401 .

Anderson, J. R., Gray, K. G., Middleton, D. G., and Young, J. A. (1964). Brit. med. 7., 2, 1630.

Bock, O. A. A., Arapakis, G., Witts, L. J., and Richards, W. C. D. (1963). Gut, 4, 106.

- and Witts, L.'J. (1963). Brit. med. 7., 2, 20

Crooks, J., Murray, I. P. C., and Wayne, E. J. (1959). Quart. F. Med., 28, 211 .
Dagg, J. H., Goldberg, A., Anderson, J. R., Beck, J. S., and Gray, K. G. (1964). Brit. med. ¥., 1 , 1349

Doniach, D., and Roitt, I. M. (1961). In Modern Trends in Endocrinology, second series, edited by H. Gardiner-Hill, p. 278. Butterworths, London.

- and Taylor, K. B. (1963). Brit. med. F., 1, 1374

Glass, G. B. J., Boyd, L. J., Gellin, G. A., and Stephanson, L. (1954). Arch. Biochem., 51, 251 .

Gunn, A., Michie, W., and Irvine, W. J. (1964). Lancet, 2, 776.

Irvine, W. J. (1963a). In The Thyroid and its Diseases, edited by A. Stuart Mason, p. 129. Pitman, London. (1963b). Quart. 7. exp. Physiol., 48, 427.

- (1963c). \%. Endocr., 26, xxii.

Davies, S. H., Delamore, I. W., and Wynn Williams, A. (1962). Brit. med. F., 2, 454.

McNicol, G. P. (1961). Amer. Y. med. Sci., 241, 336.

Marks, I. N., and Shay, H. (1961). Cited by I. N. Marks, Gastroentero$\operatorname{logy}, 1961,41,599$.

Sircus, w. (1959). 7. roy. Coll. Surg. Edinb., 4, 153.

Taylor, K. B., Roitt, I. M., Doniach, D., Couchman, K. G., and Shapland, C. (1962). Brit. med. F., 2, 1347.

te Velde, K., Abels, J., Hoedemaeker, Ph.J., Arends, A., and Niewig, H. O. (1964). Lancet, 1, 941 .

Williams, M. J., and Blair, D. W. (1964). Brit. med. 7., 1, 940.

Young, M. R. (1961). Quart. F. micro. Sci., 102, 419.

\title{
Prevention of Denervation in Bell's Palsy
}

\author{
D. TAVERNER,* M.B.E., M.D., F.R.C.P. ; M. E. FEARNLEY, † M.D., M.R.C.P. ; F. KEMBLE,* M.B., CH.B. \\ D. W. MILES,* M.B., B.SC., M.R.C.P. ; O. A. PEIRIS,* M.D., M.R.C.P., M.R.C.P.ED.
}

Brit. med. F., 1966, 1, 391-393

The natural history of idiopathic facial paralysis (Bell's palsy) has been fully described (Taverner, 1955, 1959). Movement always returns to the paralysed muscles eventually, and about three-fifths of the patients recover completely. The remainder develop denervation of the facial muscles and never recover completely. They all show associated movements of some kind, many develop contractures, and some complain of the " crocodile tear" phenomenon (Taverner, 1959). About onequarter of those who develop denervation remain permanently dissatisfied with their eventual state of recovery (Langworth and Taverner, 1963).

Many forms of treatment have been used for Bell's palsy, but there is no satisfactory evidence that any of them are effective. Controlled trials of the effect of cortisone (Taverner, 1954), physiotherapy (Mosforth and Taverner, 1958), and cervical sympathetic blockade (Fearnley et al., 1964) have all shown negative results. There is urgent need for an effective treatment to prevent the onset or minimize the degree of denervation of the facial muscles.

In this paper we report the results of a controlled trial of the effect of adrenocorticotrophic hormone (A.C.T.H. gel) in patients with Bell's palsy. A brief preliminary report has been published by Taverner and Fearnley (1965).

\section{Design of Trial}

The trial was conducted simultaneously in the Department of Electromyography, General Infirmary at Leeds, and in the Department of Physical Medicine, Orpington Hospital. All patients with Bell's palsy up to six days in duration were admitted to the trial. In each centre their names were entered on a previously prepared list allocating them randomly to treatment or control groups. They were examined clinically

- Department of Electromyography, General Infirmary at Leeds. t Department of Physical Medicine, Orpington Hospital, Orpington, and electromyographically at regular intervals for at least three months. Electromyography consisted in needle sampling of the muscles at the angle of the mouth and estimation of the conduction time from the angle of the jaw to the sampling site (Langworth and Taverner, 1963). Complete denervation is shown by complete loss of electrical excitability of the facial nerve. In partial denervation the nerve continues to respond throughout, but slowing of conduction occurs and some degree of associated movement inevitably appears (Langworth and Taverner, 1963). The threshold to anodal galvanic stimulation on the two sides of the tongue was compared in the Leeds series (Krarup, 1958 ; Peiris and Miles, 1965).

At least three months after the onset of paralysis the final evaluation was made on clinical grounds alone, and two observers agreed about each one. The results were classified as (1) complete recovery, full voluntary movement and no associated movements ; or (2) denervation, any defect of voluntary movement plus any degree of associated movement, however slight. All the patients with denervation, irrespective of degree, were classified as failures, and preference was given to the other member of the pair. Non-tied pairs from both centres in chronological order of entry were analysed sequentially by means of a closed design designated by the parameters $2 \alpha=$ $0.05,1-\beta=0.95, \theta=0.85, \mathrm{~N}=27$ (Armitage, 1960).

\section{Patients}

All patients aged 14 years or more with idiopathic facial palsy of up to six days' duration were admitted to the trial, the criteria laid down by Taverner (1955) being used. One control patient subsequently developed herpes zoster of the external auditory meatus and showed evidence of denervation. One treated patient was lost track of by administrative error. When last seen this patient was recovering rapidly, and denervation is most unlikely. The pairs containing these patients were not used in the sequential analysis chart, though the unaffected 